\title{
$x$ ニエール病の聴力予後に関する検討
}

\author{
麻生伸・水越鉄 理 \\ 渡辺行 雄 $\cdot$ 大井秀哉
}

\section{はじめに}

一般にメニエール病の聴覚所見の特徵として変動性聴 力障害があげられるが，なかには変動を繰り返しながら 難聴が進行するものから，急激に悪化してから回復しな い例や，変動の後にある時点から聴力が固定してしまう 例までその経過は様々である。一方当科では近年ィ二エ 一ル病初期に内リンパ囊減荷手術を施行した患者のなか に術後聴力が保存ないし改善した症例を経験したことか ら，めまい発作の頻発化がある場合に限り，早期手術も 考虑することを原則としている11。したがって仮にメニ エール病症例の聴力経過が事前に予測可能であれば，め まい発作が頻発化していなくとも罹患初期に聴力保存の 目的で手術を施行することも可能となる筈である。しか し現実には保存的治療に良好に反応する患者もあり，早 期の段階で治療方針を決定することは不可能と言わざる を得ない。

今回は，メニエール病確実例について，拈もに純音聴 力検査結果の経過について調査し, 蝸電図, グリセロー ル・テストの結果も参考にして, 聴力が進行性に悪化し ていく例を事前に把握することが可能か否か，またそれ らの症例に特徵的な検査所見はないかといら点について 検討したので報告する。さらに今回の対象例のなかに, 経過途中で良聴耳と難聴耳が左右入れ替わった兩側メ二 エール病の症例が 3 例あったので，この経過も併せて報 告する。

\section{対象・方法}

対象は昭和 54 年 11 月から 62 年 12 月までの約 8 年間に当 科を受診したメニエール病確実例 136 例である。メニエ ール病の診断は厚生省特定研究メニエール病調查研究班 の診断基準に従い，このらち両側性は26例（約20\%）で あった。

純音聴力検査は全て 聴力レベルに換算して平均聴力 （4 分法）などの算出を行なった。蝸電図は針電極を用

†Auditory Prognostic Findings in Meniere's Disease Shin Aso, Kanemasa Mizukoshi, Yukio Watanabe and Hideya Ohi

富山医科薬科大学耳鼻咽喉科学教室
いた鼓室内誘導法で行い, SP/AP は防音室内でドライバ ー・ユニットから与えた $100 \mathrm{dBSPL} の$ click 音刺激時 のそれぞれの振幅から算出した。当科では以前に報告し た通り2) $\mathrm{SP} / \mathrm{AP} \leqq 0.37$ を正常 $\mathrm{SP}$ とて沶り，本稿で もこれに準じた。グリセロール・テストは $10 \%$ グリ七ロ ール（5\%フラクトース付加）製剤 $500 \mathrm{ml}$ を約 2 時間 で点滴静注する方法で行なった ${ }^{3)}$ 。判定は 2 周波数以上 で各々 $10 \mathrm{~dB}$ ずつ以上の聴力改善を認めた場合に陽性 とした4)。

\section{結 果}

1) 初診時の平均聴力レベル：初診時の平均聴力レベ ルをめまいの発症から初診までの期間（罹病期間）に分 けて調べた（表 1 ）。但し両側例は初発がいずれの耳か 不明の症例もあるため, 今回は全て除外した。3 年末満 の症例73例では $30 \mathrm{~dB}$ 未満が28例 $(38 \%), 30 \sim 60 \mathrm{~dB}$ が31例 (43\%)，60 dB〜90 dB が14例（19\%）であるの に対し， 3 年以上の 37 例では $30 \mathrm{~dB}$ 未満が 6 例 (16\%), $30 \sim 60 \mathrm{~dB}$ が 15 例 (41\%)，60 dB 90 dB が 16 例（43 \%) と罹病期間が長い汪ど聴力レベルは上昇し，3年を 境に $30 \mathrm{~dB}$ 末満の症例と $60 \mathrm{~dB}$ 以上の症例の出現率が ほぼ逆転することが分かった。な和 $90 \mathrm{~dB}$ 以上の平均 聴力を示守症例は今回の対象中にはなかった。

2 ) 初診時の平均聴力レベルと聴力像との関係 : 初診 時の平均聴力レベルを 3 つに分け，聴力像を 4 型に分類

表 1 初䛦時の平均聴力レベル

\begin{tabular}{ccrcr}
\hline $\begin{array}{c}\text { 発症から初診 } \\
\text { までの期間 }\end{array}$ & $\begin{array}{c}30 \mathrm{~dB} \\
\text { 未満 }\end{array}$ & $\begin{array}{l}30 \sim \\
60 \mathrm{~dB}\end{array}$ & $\begin{array}{l}60 \sim \mathrm{dB} \\
90\end{array}$ & 計 (例) \\
\hline 1 年未満 & 20 & 22 & 8 & 50 \\
$1 \sim 2$ 年 & 7 & 4 & 4 & 15 \\
$2 \sim 3$ 年 & 1 & 5 & 2 & 8 \\
$3 \sim 4$ 年 & 1 & 3 & 3 & 7 \\
$4 \sim 5$ 年 & 0 & 1 & 2 & 3 \\
5 年以上 & 5 & 11 & 11 & 27 \\
\hline 計 (例) & 34 & 46 & 30 & 110 \\
\hline
\end{tabular}


してその関係を調べた（表 2)。聴力像で最も多いのは 低音障害型で全体の $41.8 \%$ ，次涪高音障害型 $24.5 \%$ ，以 下山型，水平型の順になった。

3 ) 初診時の聴力像と罹病期間との関係 : 初診時の聴 力像と罹病期間との関係を表 3 亿示した。この表に示し た 5 年以上経過例 27 例中平均 $60 \mathrm{~dB}$ 以上の聴力障害を 示したのは, 水平型 3 例, 低音障害型 2 例, 高音障害型 3 例, 山型 3 例の計 11 例 $(41 \%)$ で, 聴力像による差は なかった。

4） 1 年以上聴力を経過観察し得た症例：次に 1 年以 上聴力を追跡し得た一側性メニエール病29例について, 罹病期間別に 1 年後の聴カレベルを調べた（表 4 )。初

表 2 初診時の平均聴力レベルと聴力像との関係

\begin{tabular}{rcrrrr}
\hline & $\begin{array}{c}30 \mathrm{~dB} \\
\text { 未満 }\end{array}$ & $\begin{array}{l}30 \sim \\
60 \mathrm{~dB}\end{array}$ & $\begin{array}{l}60 \sim \\
90 \mathrm{~dB}\end{array}$ & 計 $(\%)$ \\
\hline 水 平 型 & 5 & 4 & 9 & $18(16.4)$ \\
低音障害型 & 10 & 24 & 12 & $46(41.8)$ \\
高音障害型 & 11 & 11 & 5 & $27(24.5)$ \\
山 型 & 8 & 7 & 4 & $19(17.3)$ \\
\hline 計 (例) & 34 & 46 & 30 & $110(100.0)$ \\
\hline
\end{tabular}

表 3 初診時の聴力像と罹病期間との関係

\begin{tabular}{|c|c|c|c|c|c|c|c|}
\hline & $\begin{array}{l}1 \text { 年 } \\
\text { 未満 }\end{array}$ & 2 年 & $\begin{array}{l}2 \text { 年 } \\
3\end{array}$ & $\begin{array}{l}3 \text { 年 } \\
4 \text { 年 }\end{array}$ & $\begin{array}{l}4 \text { 年 } \\
5\end{array}$ & $\begin{array}{l}5 \text { 年 } \\
\text { 以上 }\end{array}$ & 計 (例) \\
\hline 水平 型 & 10 & 2 & 0 & 1 & 0 & 5 & 18 \\
\hline 低音障害型 & 22 & 5 & 7 & 3 & 0 & 9 & 46 \\
\hline 高音障害型 & 12 & 6 & 0 & 1 & 3 & 5 & 27 \\
\hline 山型 & 6 & 2 & 1 & 2 & 0 & 8 & 19 \\
\hline 計（例） & 50 & 15 & 8 & 7 & 3 & 27 & 110 \\
\hline
\end{tabular}

表 41 年以上聴力を経過観察した症例

\begin{tabular}{|c|c|c|c|c|}
\hline \multirow{2}{*}{$\begin{array}{l}\text { 発症から初診 } \\
\text { までの期間 }\end{array}$} & \multicolumn{3}{|c|}{1 年後の聴力レベル } & \multirow{2}{*}{ 計 (例) } \\
\hline & 悪化 & 改善 & 不変 & \\
\hline 1 年未満 & 1 & 3 & 9 & 13 \\
\hline 1 ～ 2 年 & 0 & 0 & 6 & 6 \\
\hline 2 ～ 3 年 & 0 & 0 & 0 & 0 \\
\hline $3 \sim 4$ 年 & 2 & 0 & 0 & 2 \\
\hline $4 \sim 5$ 年 & 0 & 0 & 0 & 0 \\
\hline 5 年以上 & 1 & 0 & 7 & 8 \\
\hline 計（例） & 4 & 3 & 22 & 29 \\
\hline
\end{tabular}

診 1 年後に平均聴力レベルで $10 \mathrm{~dB}$ 以上の変化があっ た例を調べたところ，この表のよらに発症 3 年未満では 19例中悪化例 1 例, 改善例 3 例，不変例15例とばらつき があったのに対し, 発症 3 年以降の例では改善例が全く みられず，悪化例か，不変例すなわち聴力固定例のみだ った。

5 ）聴力レベルと異常 - SP の出現率との関係 : 平均 聴力レベルを $30 \mathrm{~dB}$ で分けて, 螖電図の異常一SP およ び正常一SP の出現率を調べたところ（表 5)，30 dB 以 上の群で異常 - SP の出現率が有意に高いことが分かっ た $(\mathrm{p}<0.05)$ 。

6 ）罹病期間とグリセロール・テストとの関係 : 発症 から初診までの罹病期間とグリセロール・テストの陽性 率との関係を調べると（表 6 )，3 年未満の群にグリセ ロール・テスト陽性例が有意に多いことが分かった（p

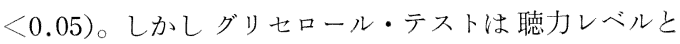
関係がなく，蝸電図は罹病期間と関係を認めなかった。

7 ）グリセロール・テスト, 蝸電図の予後推定能力 : 次に発症 1 年未満にグリセロール・テスト, 蝸電図を施

表 5 聴力レベルと異常一SP の出現率との関係

\begin{tabular}{cccc}
\hline & 異常—SP & 正常一SP & 計（例） \\
\hline $30 \mathrm{~dB}$ 未満 & 14 & 16 & 30 \\
$30 \mathrm{~dB}$ 以上 & 35 & 12 & 47 \\
\hline 計 (例) & 49 & 28 & 77 \\
\hline & & & $\mathrm{p}<0.05$
\end{tabular}

表 6 罹病期間とグリセロール・テストの関係

\begin{tabular}{cccc}
\hline & $\mathrm{G}(+)$ & $\mathrm{G}(-)$ & 計 (例) \\
\hline 3 年未満 & 32 & 21 & 53 \\
3 年以上 & 10 & 18 & 28 \\
\hline 計 (例) & 42 & 39 & 81 \\
\hline & & & $\mathrm{p}<0.05$
\end{tabular}

表 7 グリセロール・テスト，蝸電図の 予後推定能力

\begin{tabular}{|c|c|c|c|c|c|c|}
\hline & 悪化 & 改善 & 変動 & 不変 & 不明 & 計 (例) \\
\hline$G(+)$ & 1 & 3 & 1 & 4 & 9 & 18 \\
\hline$G(-)$ & 4 & 0 & 0 & 1 & 8 & 13 \\
\hline 異常一SP & 4 & 2 & 1 & 3 & 9 & 19 \\
\hline 正常一SP & 2 & 1 & 0 & 1 & 7 & 11 \\
\hline
\end{tabular}



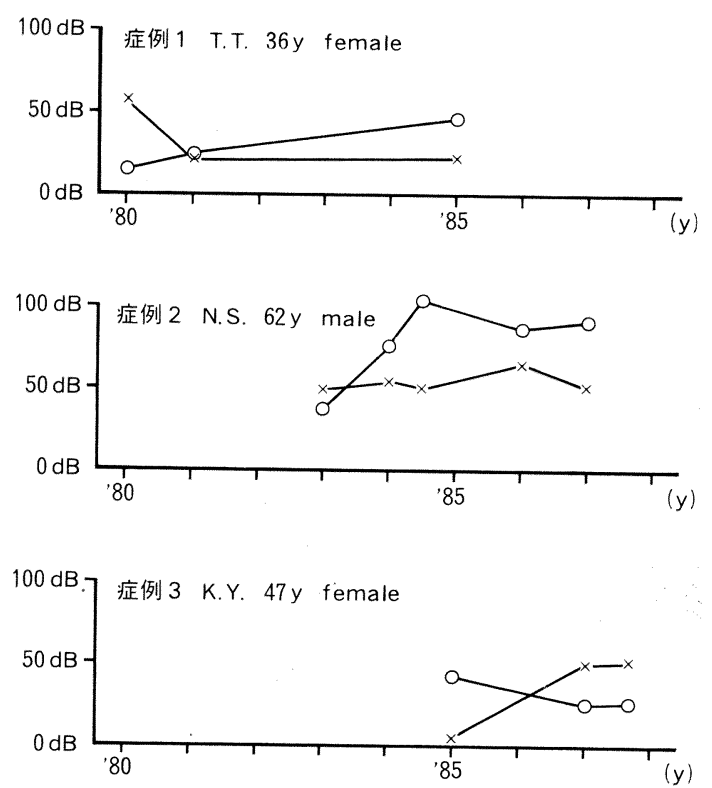

図 1 経過観察中に両耳聴力が逆転した 両側性メニエール病の 3 例

行した症例の 1 年後の聴力を調べた(表 7 )。すなわち発 症早期に聴力が悪化する例をグリセロール・テスト，蝸 電図で見つけることが出来るか否かをみたものである。

グリセロール・テストでは発症 1 年未満の検查で陽性 の症例が18例，陰性例が13例あった。陽性例のうち平均 聴力レベル $10 \mathrm{~dB}$ 以上の悪化例 1 例, 改善例 3 例, 悪 化一改善を繰り返す変動例が 1 例, 不变例が 4 例だった のに対し，グリセロール㓌性例では改善, 変動例は全く みられず，悪化例 4 例，不変例 1 例のみであった。

これに対し, 蝸電図検査では, 異常 - SP が19例, 正 常 - SP が11例であった。1 年後の聴力悪化例は, 異常 一SP を示した例の方が多かった（4例）が，グリセロ ール・テストほどはっきりした傾向は出なかった。

8 ）経過観察中に両耳聴力が逆転した症例：今回の対 象中, 経過観察中に良聴耳が悪化し難聴耳が改善して, 両耳聴力が逆転した両側性メニエール病症例が 20 例中 3 例あった（図 1)。3 例とも逆転現象は初診から 2 年以 内に起こっており, 図中のちょらど交差する時期に周波 数別に細かく観察すると, 水越ら ${ }^{5)}$ の報告例のように, さらに短期間にあたかもシーソーの様に両耳聴力が交代 性に変動している例もあった（図 1, 症例 2)。

\section{考察}

一般に切替6) の図式のようにメニエール病の難聴が変 動しながら進行するならば, 最終的には全周波数で域值 が上昇して水平型から襲型に近い型でスケールアウトと なって行くものと推察される。しかし今回の対象中，初
表 8 早期に $60 \mathrm{~dB}$ 以上の難聴をきたした 8 例

\begin{tabular}{ccccc}
\hline 症 例 & 聴力 & Glycerol & ECoG & 経過 \\
\hline 1. MH & $60.0 \mathrm{~dB}$ & $(+)$ & 未施行 & 不変 \\
2. I T & 76.2 & $(+)$ & 未施行 & 不変 \\
3. F H & 67.5 & 未施行 & 正常 & 不変 \\
4. O S & 81.2 & $(-)$ & 未施行 & 手術 \\
5. Y Y & 71.2 & $(+)$ & 異常 & 不明 \\
6. I A & 62.5 & $(+)$ & 未施行 & 不明 \\
7. T M & 62.5 & $(+)$ & 異常 & 不明 \\
8. S S & 72.5 & $(+)$ & 正常 & 不明
\end{tabular}

診時聴力が $60 \mathrm{~dB}$ 以上の例は 30 例あったが，特に聴力 像に有意の差はみられなかった。さらにこの30例中発症 から初診までの罹病期間が 1 年末満の例が 8 例存在し, Stahle $ら^{7)}$ も報告している通り発症の早期に急激に聴 力障害が進行する 1 群の存在が示唆された。この 8 例に ついてグリセロール・テストと蝸電図の結果をまとめた のが表 8 だが，グリセロール・テストは検査を施行し得 た 7 例中 6 例までが陽性で，きわめて高い陽性率を示し た。蝸電図は聴力域值が高く検査不可能の症例があった ため 4 例にしか施行できず，そのらち異常 - SP を示し たのは 2 例のみであった。これらは 1 例を除いて保存的 治療を行なったが, 改善も悪化もせず聴力がほぼ不変の 例ないし聴力経過不明の症例であった。また内リンパ囊 減荷術を施行した 1 例も聴力は固定したままで回復しな かった。すなわちこれらの症例は悪化する例が少ないと はいえ，聴力の予後は良好とはいい難い。

メニエール病発症初期症例はグリセロール・テスト陽 性率が高く, Tonndorf ${ }^{8)}$ も述べているように, これは恐 らく基底板やライスネル膜の弾性が未だ保持されている ためと考えられ, 病態の進行につれてこの弾性が消失し, 不可逆性となっていくことが予測された。しかし上述の 発症早期に $60 \mathrm{~dB}$ 以上の聴力レベルを示した症例は, グリセロール陽性例が多かったにも関わらず実際には改 善傾向を示さず，聴力が固定してしまう critical point が $60 \mathrm{~dB}$ あたりに存在する可能性を示唆する結果とな った。また表 4 に示したように, 初診から 1 年後に聴 力改善を示したのは平均聴力レベルの $10 \mathrm{~dB}$ で観察す ると 3 例 (10.3\%) しかなく, $20 \mathrm{~dB}$ では 1 例 (3.4\%) のタであった。北原 ${ }^{9)}$ は 5 年以上保存的に経過観察した 105 例について調査し，改善 $9 \%$ ，不変 $55 \%$ ，悪化 $36 \%$ と報告している。以上からメニエール病特有の自然経過 も考え合わせると, Arenberg ${ }^{10)}$ も述べている通りメ二 エール病の難聴を改善させる有効な治療薬は殆どないに 
等しいといわざるを得ないのが現状である。

そこで以上のような難聴の進行する症例を事前に把握 することが出来ないかといら点について検討した。これ が可能であればそのような症例に集中的に保存的，ある いは手術的治療を施すことができ治療成績の向上につな がると考えた。

当科では従来よりメニエール病，およびその関連疾患 を中心にグリセロール・テスト，蝸電図をルーチン検査 として施行し, 両検查と聴力レベル, 罹病期間との関係 を調べてきた2)。今回の対象について同様の関係をみた のが表 5 および表 6 であるが，蝸電図の-SP 異常増大 現象（dominant-SP） は聴カレベルが高いほど多くみら れ有意差があったのに対し，グリセロール・テストは聴 カレベルとは無関係で寧ろ罹病期間に関係しているとい ら結果が得られた。メニエール病の病態の進行は個々の 症例によって様々であり, 罹病期間と聴力レベルもパラ レルの関係にあるとは言い難い。その点蝸電図とグリセ ロール・テストはその陽性となる機序が異なるが故に, 両検査を同一時期に施行することは病態把握の上で有意 義と言える。

この両検査を発症 1 年未満の比較的早期に施行した例 は表 7 に示した通りである。検査 1 年後に聴力検査を施 行し得た症例は比較的少ないが，グリセロール・テスト 陽性例では 9 例中 1 例の久が悪化し他の 8 例は改善, 変 動, 不変の非悪化群であった。これに対して陰性例は, 悪化が 4 例に対し, 非悪化例は不変の 1 例のみで改善, 変動例はなく, 明らかにグリセロール・テスト陰性例の 方が聴力の予後が悪いことが判明した。しかし螖電図 は異常 -SP 例のらち, 悪化 4 例, 非悪化 6 例, 正常 - SP 例のらち, 覀化 2 例, 非悪化 2 例とグリセロール・ テストほど明らかな関係を示さなかった。これは近年当 科でメニエール病初期で比較的聴力レベルの高い初診患 者が増えている（表 1）ことが一因とも考えられる。す なわらこれらの患者はグリセロール・テスト陽性, 異常 一 SP を示すことが多いが，上述の通り聴力域值が高け ればそのまま固定してしまい, 聴力不変群の例数を増や していると考えられるからである。

以上のことから治療上最も留意すべき患者群は発症 1 年末満でグリセロール・テスト陰性の例であるが，これ らは朴沢ら ${ }^{11)}$, Arenberg ${ }^{2)}$ の報告にもある通り手術治 療にも抵抗することが予測され，その治療はきわめて困 難と思われる。第 2 の群としてグリセロール・テスト陽 性の中でも聴力が変動ないし不変の経過を示した群があ る。これは前述の如く経過観察例の半数以上を占めてお り, 覀化はせずとも予後が良好とは言い難い。さらにこ れらの症例は発症初期でもあり十分治療に反応する可能
性もあるため，この患者群を聴力改善の方向八向かわせ るべく集中的に治療することは有意義であると思われ る。

最後に数は少ないが, 今回 3 例呈示したよらに経過途 中で左右の聴力が逆転するような例がある。このうち 1 例（図 1, 症例 1) は蝸電図は雨耳とも正常一SP を示 し，グリセロール・テストは両耳とも陰性であったが， 水越ら ${ }^{5)}$ の報告のように, グリセロール・テストによっ てシーソー化したり悪化したりした周波数はなかった。 他の 2 例はグリセロール両耳陽性，かつ両耳とも異常 -SP を示した。現在初めの 1 例（症例 1）は未だ聴力 が固定傾向になく変動しているが，他の 2 例は，いずれ も一旦聴力が逆転して両耳聴力が離れてしまらと再び逆 転することはなく，良聴耳から難聴耳に変わった耳は固 定していく傾向にあった。したがって一旦悪くなった方 の耳には十分点意を払い, 強力な治療を施すことが望ま しいと言える。

メニエール病の聴力経過は実に様々であり悪化例を見 つけだして有効な治療を進めることは, 非常に困難と言 わざるを得なかった。しかし今回グリセロール・テスト によってある程度聴力経過の予測のつく症例も若干名存 在することが分かったので，今後更に症例を増やして検 討する意義はあると思われた。

\section{まとめ}

メニエール病 136 名の聴力経過について蝸電図, グリ セロール・テストの結果を参考に検討したところ以下の 成績を得た。

1) 発症から 3 年を境に $30 \mathrm{~dB}$ 末満の症例と $60 \mathrm{~dB}$ 以上の症例の出現率が逆転し, 経過が長いほど聴力レベ ルは上昇する傾向にあったが，発症早期に急激に聴力が 悪化する 1 群が存在した。

2) 初診から 1 年後の聴力を検討すると, 発症 3 年末 満の症例では19例中憲化 1 例, 改善 3 例, 不変15例であ り，3 年以降の例では改善例はみられず，悪化 3 例，不 変 7 例のダであった。

3）発症から 1 年未满でグリセロール・テスト陽性の 例では 1 年後の聴力が悪化 1 例, 改善 3 例, 変動 1 例, 不変 4 例であったのに対し，グリ七ロール・テスト㓌性 例では悪化 4 例, 改善, 変動例なし, 不変 1 例であり, グリセロール・テストが予後推定能力をある程度有する ことが分かった。

4）両側性メニエール病の中に経過中左右の聴力が逆 転する例があり，これを呈示するとともに，後から悪化 した方の耳が固定傾向にあることを述べた。

\section{謝辞}

本研究は厚生省特定疾患前庭機能異常調査研究班の研 
究援助により行なわれたものである。

\section{文献}

1）水越鉄理，他：メニエール病に対する手術療法の神 経耳科学的評価. Equilibrium Res Suppl 2:130137, 1987

2) 麻生 伸, 水越鉄理, 他 : メ二エール病の蝸電困所 見一グリセロール・テストとの比較一。耳鼻臨床

補 $8: 242-248,1986$

3 ）水越鉄理，他：メニエール病に対するグリセロール 静注試験について. 耳鼻臨床 $75: 2278-2284,1982$

4) 麻生 伸, 水越鉄理, 他 : グリセロール静注試験一 判定法抒よび経口法との相違点一Audiology Japan 32 : 207-211, 1989

5 ）水越鉄理, 他: 両側交代性に聴力変動を示した両 側性メニエール病の一症例. 耳鼻臨床 73:18251831,1980

6) 切替一郎 : 新耳鼻咽喉科学. 163頁, 南山堂, 東京, 1982

7 ) Stahle J : Advanced Meniere's disease. A Study of 356 severely disabled patients. Acta Otolaryngol $81: 113-119,1976$

8 ) Tonndorf $\mathrm{J}:$ Mechanical causes of fluctuant hearing loss. Otolaryngol Clin N Am 8 : 303-311, 1975

9 ）北原正章：メニエール病の基礎と臨床. 第82回日本 耳鼻咽喉科学会総会宿題報告 (京都), 1981

10) Arenberg $K$, et al: Therapeutic options in Meniere's disease. Arch Otolaryng 103: 589593, 1977

11）朴沢二郎，他：メニエール病に扣けるグリセロール 試験結果とポルトマン手術成績との関係について。 耳鼻臨床 $68: 1427-1433,1975$

12) Arenberg $K:$ The prognostic value of the glycerol test. Otolaryngol Clin N Am 13:693-701, 1980

\section{Abstract}

In patients with Meniere's disease, hearing has been thought to fluctuate, especially in the early stage. However, in some cases, hearing deteriorates suddenly and does not recover even in early stage. In other cases, hearing deteriorates gradally to some degree.
We have attempted to establish prognostic criteria for hearing impairment. Pure-tone audiometry, the glycerol test, and electrocochleography performed in 136 patients with definite Meniere's disease were analyzed retrospectively.

1) Among 73 patients with an interval of less than 3 years between the first attack of vertigo and the first audiometry, the average hearing threshold was less than $30 \mathrm{~dB}$ in 28 patients $(38 \%)$, and $60 \mathrm{~dB}$ or more in 14 patients (19\%). On the other hand, among 37 patients with an interval of 3 or more years $6(16 \%)$ had had hearing thresholds less than $30 \mathrm{~dB}$ and $16(43 \%)$ had average hearing thresholds of $60 \mathrm{~dB}$ or more. Thus patients with a longer duration of Meniere's disease generally have more severe hearing loss. We also observed that in some patients hearing deteriorated rapidly even in the early stage as Stahle reported (1976).

2 ) In 29 patients, we could repeat pure-tone audiometry one year after the first audiometry. Of the 19 patients with a history of less than 3 years, one patient had poorer hearing, 3 showed improvement, and in 15 there was no change in the average hearing threshold. Of the 10 patients with more than 3 years of symptoms none had improved hearing, 3 had worse hearing and in 7 there was no change.

3 ) Of the 9 patients with a positive glycerol test with a history of less than one year, one patient had deterioration, 3 improvement, one fluctuation and 4 no change in the average hearing threshold. However, in 5 patients with a negative glycerol test, 4 had worsening and one no change, no improvement and fluctuation in hearing.

These clinical observations suggest that the glycerol test may provide some vital information for predicting the prognosis in hearing impairment in Meniere's disease.

Key words : Meniere's disease, pure-tone audiometry, glycerol test, electrocochleography

$$
\left(\begin{array}{l}
\text { 原稿到着: 平成 } 1 \text { 年 } 2 \text { 月 } 6 \text { 日 } \\
\text { 別刷請求先 : 麻生 伸 } \\
\text { \%930-01 富山市杉谷 } 2630 \\
\text { 富山医科薬科大学耳鼻咽喉科学教室 }
\end{array}\right)
$$

